\title{
Sustainable Forest Management. Polish Solutions in a Legal Perspective
}

\section{Trwale zrównoważona gospodarka leśna. Polskie rozwiązania w ujęciu prawnym}

\author{
http://dx.doi.org/10.12775/PYEL.2015.002
}

\begin{abstract}
The fundamental aim of this article is the study of the norms and legal provisions which ensure the implementation of sustainable forest management (SFM) on grounds of the Polish Act on Forests. SFM is a part of sustainable development which as a concept - as it is indicated by some researchers - lost its original meaning. Therefore, it calls for a return to its primary sources. The concept of sustainable development directly emerged from forestry, and the model as well as the assumptions of SFM are very close to the original meaning of this concept. Thus, considerations concerning SFM have been conducted on the basis of sustainable development. There have been also de lege ferenda demands, covering legal aspects of the criteria and ways of measuring of SFM implementation, enunciated.
\end{abstract}

Doctor of Laws, Assistant Professor at the Department of Administrative Law and Administrative Business Law, Koźmiński University, Warsaw. 
Keywords: Sustainable development; sustainable forest management; forest principles; forestry law; Simplified Forest Management Plans; Forest Management Plans.

\section{Streszczenie}

Podstawowym celem nieniejszego opracowania jest analiza norm i przepisów prawnych gwrantujących realizację trwale zrównoważonej gospodarki leśnej na gruncie polskiej ustawy o lasach. Trwale zrównoważona gospodarka leśna stanowi fragment zrównoważonego rozwoju, który jako koncepcja - jak wskazują niektórzy badacze - utracił swój pierwotny sens. Stąd też postuluje się powrót do jego źródeł. Koncepcja zrównoważonego rozwoju wywodzi się bezpośrednio z leśnictwa, zaś model oraz założenia trwale zrównoważonej gospodarki leśnej są bardzo zbliżone do pierwotnego znaczenia tej koncpecji. Rozważania dotyczące trwale zrównoważonej gospodarki leśnej zostały więc ukazane na tle rozwoju zrównoważonego. W tekście sformułowano postulaty de lege ferenda obejmujące prawne aspekty kryteriów i sposobów pomiaru realizacji trwale zrównoważonej gospodarki leśnej.

Słowa kluczowe: Rozwój zrównoważony; trwale zrównoważna gospodarka leśna; zasady gospodarki leśnej; prawo leśne; uproszczony plan urządzenia lasu; plan urządzenia lasu.

\section{Introduction}

Sustainable development is an interdisciplinary concept and a research subject of extremely different science fields and disciplines: from socioeconomic sciences including economics, sociology or political science to natural sciences, which encompass, inter alia, chemical sciences, physical sciences or forestry. Currently there is no doubt that - despite the fact that sustainable development is a difficult to define, ambiguous concept - it plays an increasingly important role not only on the theoretical (cognitive) level, but also in all possible practical aspects and fields. It is clear that the concept of sustainable development is gaining more and more recognition, which is confirmed by a great amount of research and publications dedicated to it ${ }^{1}$.

1 See for example: Theories of Sustainable Development, eds. J. Enders, M. Remig, London 2014;Transdisciplinary Sustainability Studies. A Heuristic Approach, eds. K. Huutoniemi, 
These remarks fully apply to law and legal sciences due to the fact that the concept of sustainable development is reflected in the existing law sustainability is an integral normative concept and a principle of international law (EU law), as well as the legal systems of particular states, including the Polish legal order.

Although the boom of sustainable development came within the last three decades of the twentieth century, this concept was incorporated into the Polish legal order after the collapse of communism across central and eastern Europe. This was due to the fact that the Polish People's Republic was based on the idea of a centrally planned state-controlled economy, in which there was no place for sustainable development. Only severe and deep structural social, economic and ecological (environmental) destructions caused by nearly 50 years of communism, led to a situation in which during and after the political transformation - sustainability has been recognised and appreciated in Poland. Therefore, it has been incorporated by the provisions of both of the Constitution of the Republic of Poland, and a number of administrative and legal acts, such as for example: nuclear law, telecoms law, water law, environmental law or forestry law.

The scope of this article covers the analysis of sustainable forest management (SFM), which is a part of sustainable development. In concrete terms, "(...) the term of sustainable forest management is not evidently equivalent to the concept of sustainable development. However, the activities conducted in the range of SFM are supposed to lead to such development"2.

The concept of SFM plays a leading role on grounds of forestry law. It constitutes one of the basic principles of forest management and

P. Tapio, London 2014; Th. Miller, Reconstructing Sustainability Science. Knowledge and Action for a Sustainable Future, Routledge 2014; S. Fredericks, Measuring and Evaluating Sustainability, London and New York 2013; Values in Sustainable Development, ed.J. Appleton, Routledge 2015; J. Blewitt, Understanding Sustainable Development, London 2008; Sustainability. Key Issues, eds. H. Kopnina, E. Shoreman-Ouimet, New York 2015; K. W. Robert, Th. M. Parris, A. A. Leiserowitz, What is Sustainable Development? Goals, Indicators, Values, and Practice, Environment: Science and Policy for Sustainable Development 2005, Vol. 47, Issue 3, p. 8-21; K. Pezzoli, Sustainable Development: A Transdisciplinary Overview of the Literature, Journal of Environmental Planning and Management 1997, Vol. 40, p. 549-574 and literature indicated and quoted in these books and articles.

2 Z. Bukowski, Koncepcja zrównoważonego rozwoju a gospodarka leśna, in: Ochrona i użytkowanie zasobów leśnych, eds. M. Woźniak, M. Kościelniak-Marszał, Wrocław 2015, p. 94 . 
significantly determines the interpretation of the provisions of the Act of 28 September 1991 on Forests ${ }^{3}$. Therefore, it is in fact a general legal principle of the forestry law and it fundamentally influences the interpretation of forestry provisions and the directions of its regulations as well.

The key objective of this research paper is to indicate how the Polish Legislator: (1) defines the concept of SFM, and (2) ensures - through institutions and legal regulations - the implementation of the principle of sustainable forest management. Answering these questions will require taking into account a number of more specific issues, which is going to have an influence on the structure and the order of this analysis.

The first part of this article is going to be dedicated to the concept of sustainable development in genere, which will cover mainly definitional characteristics and features of this concept. The second part will focus on the legal nature of this concept. The third part will include deliberations on SFM, in particular its genesis and evolution on grounds of international law. Moreover, this part will investigate the definition of SFM in the Polish legal order and the analysis of legal institutions and provisions which are intended to ensure its implementation. General conclusions are going to cover de lege ferenda remarks focused on pointing out the necessity of regulation of the measurement of the implementation of SFM.

\section{Sustainable development - definition, features and specifics}

At the core of the genesis of the concept of sustainable development, generally speaking, lays a conviction of limitations and (natural) resource finiteness. Continuous development and technological progress, as well as constantly increasing needs of fast-growing population have led to more extensive use of natural resources. At the same time, the need to shape the optimal economic development which would ensure emerging of the basis of prosperity and social development without having a significant negative impact on the pool of resources and the environment, was

3 Journal of Laws of 2011, No 12, item 59 with amendments, consolidated text. Hereinafter further reffered to as 'the Act on Forests' 
recognized. It had to - in the long term - lead to attempts to reconcile these aspects and to introduce tools to implement such project. Apart from the relevance and possible practical applications of sustainable development, we should emphasize that it this concept which - according to its creators and developers - was supposed to have ensured “(...) development that meets the needs of the present without compromising the ability of future generations to meet their own needs".

This definition - introduced by the World Commission on Environment and Development in 1987 (so called the Brundtland Commission), which was formed after the United Nations Conference on the Human Environment held in Stockholm in 1972 (first international conference concerning development and environment) - became the most popular, best known, laconic, and at the same time, vague idea of sustainable development. Since then, this concept has been constantly developed and many attempts have been made to apply it to different spheres of human activity. At the same time, ways of perceiving and understanding sustainability have been determined by the different approaches and diversified methodology of the various research disciplines and sciences. As a result, "(...) it (concept of sustainable development - J. Ch.) continues to be more rethoric than fact. Nations, governments and industries are not walking their talk of sustainable development. And when the noise on sustainable development is peeled from actual development planning and policy in many countries, it remains just that, noise" ${ }^{4}$. I do not share this pessimistic vision, but it is true that sustainable development is often still "more retoric than fact". However, there are areas and fields in which this concept is realized (implemented), and therefore they should be payed special attention to. Forestry, based on SFM, is definitely such an area.

In addition, problems in defining the concept of sustainable development are essentially caused by - as aptly H. M. Osofsky points out - four key factors. Firstly, there are inseparable tensions existing in the term sustainable development. This is because - in order to maintain the balance among competing claims - it is necessary to change certain behaviors, for example to limit the exploitation of resources. Secondly, there is the matter of international power dynamic which basically occurs in three different ways: (1) constraing the growth of developing countries because the need

4 B. S. Malaynag III, Rethinking Sustainable Development, Philippine Law Journal 2006, Vol. 81, p. 120. 
of protection of the environment and resources would be inequitable since the developed conutries have had a chance to grow causing environmental degradation; (2) the rates of population growth and consumption are major causes of environmental degradation, but at the same time these rates are strongly differentiated in particular countries and (3) environmental degradation is caused due to different factors in the developed countries and different in developing countries. Thirdly, sustainable development issues manifest themselves at different levels, including the local, regional, national and global levels. Sustainable development problems are not only the domain of domestic or international authorities (bodies), but they seem to be cross-cutting. Fourthly, there is no doubt, that the world is constantly evolving, and so sustainable development at all of the abovementioned levels must follow and keep up with such inevitable changes 5 . It seems, then, that at the root of the problems in the construction of the objective and inclusive definition of sustainable development are factors that not only are very dynamic and variable in time and space, but also depend on sectional interests or concerns which are very difficult to overcome.

However, summary of the various existing definitions of sustainable development leads to the conclusion that, in general, such "definitions regarding the sustainability are approached in the vision of reconciliation between the economy and the environment on a new way supporting the human progress, not only in several places and for several years, but for the entire planet and for a future as long as possible"6. So it is clear that as assumed by most of approaches to sustainable development - it is "(...) a union of three dimensions - economic, social and ecologic"

So then the question arises: how should these dimensions be reconciled? How should the needs (demands) and resources be combined? Answering these questions gets us to two different types of concept of sustainable development. According to C. C. Williams and A. C. Millington, the first one is known as weak sustainability (shallow environmentalism) and it assumes that man should expand the pool of resources, e.g. through renewable energy sources. Therefore, this concept is an anthropocentric and

5 H. M. Osofsky, Defining Sustainable Development After Earth Summit 2002, Loyola of Los Angeles International and Comparative Law Review 2003, Vol. 26, p. 112-119.

6 M. E. Gherasim, G. Tanase, The Fundamentals of Sustainable Development, Contemporary Readings in Law and Social Justice 2012, Vol. 4, No 1, p. 452. 
is based on the belief that there is no need to make major changes in people's requirements with respect to the environment and resources. At the same time, it is invariably focused on economic growth ${ }^{8}$. The second type (kind) of sustainable development derives from different assumptions. It is so called deep ecology or strong sustainable development ${ }^{9}$ and the essence of this approach is that human kind should reconsider its needs because resources are finite, and so it is rather "ecocentrist” than anthropocentric when it comes to relation between people and nature. It also strongly criticizes economic development as a major factor of environment degradation ${ }^{10}$. However, this division should not be considered dichotomous (detachable). There is a third possibility, a kind of hybrid approach that combines selected elements of weaker and stronger sustainable development. This is moderate sustainability which "(...) seeks to both expand the stock of resources and reduce demands on this stock in order to conjoin resources and demands"11.

In a broader perspective these different approaches clearly show that the meaning of sustainable development varies strongly and the current meaning of this concept is determined not only by those who use it, but also by which of the three basic spheres (social, economic, environmental) is emphasized ${ }^{12}$. Despite the fact that there is no doubt that these three elements are the cornerstones and foundations of sustainable development, it still remains a vague and unclear concept. Perhaps this situation has been caused by theoretical considerations which focused on building more and more unnecessary (most frequently) definitions of sustainable development, which - as a result - occurred in spoiling this concept. Consequently, sustainable development has lost its original potential ${ }^{13}$. That is why “(...) fixing the concept will require going back to its origins, and especially stressing the integration of economic and ecological systems while leaving it up to competent local institutions to decide how to set and pursue their

8 C. C. Williams, A. C. Millington, The Diverse and Contested Meanings of Sustainable Development, The Geographical Journal 2004, Vol. 170, No 2, pp. $100-101$.

9 Ibidem, p. 102.

10 Ibidem, p. 101-103.

11 Ibidem, p. 100.

12 A. Buchs, O. Blanchard, Exploring the Concept of Sustainable Development Through Role-Playing, The Journal of Economic Education 2011, Vol. 42 No 4, p. 393.

13 A. H. T. Fergus, J. I. A. Rowney, Sustainable Development: Lost Meaning and Opportunity?, Journal of Business Ethics 2005, Vol. 60, p. 25. 
own priorities" ${ }^{\prime 4}$. At this point, it is necessary to pay more attention to this remark. It indicates the demand for a specific decentralization of sustainable development which stems from a belief that "local needs and interest will necessarily vary, sustainable development must be redefined repeatedly, from the bottom up, wherever it is to be put in practice" ${ }^{15}$. At the core of this statement there is a conviction that - due to the fact that the concept of sustainable development requires constant redefining - it is not possible to establish its static, persistent and long-term definition. At the same time, the return to the origins of sustainable development seems essential. It actually means the return to the way of understanding sustainability in the way the Stockholm Declaration or the Brundtland Report did, and this also may be the evidence of the failure of the subsequent concepts and principles of sustainable development, and furthermore - what must be especially emphasized - the failure of its (full) implementation. Is this vision - in fact pessimistic - real and true? The following is an attempt to prove that there are indeed areas in which sustainable development has been implemented and it is being realized. In my opinion such area (field) is Polish forestry law, in which sustainable forest management is very close to the original concept of sustainability and sustainable growth.

\section{Sustainable development and legal provisions}

\section{1. General remarks}

An area in which sustainable development is being carried out and plays a fundamental role is law and legal regulations. This includes both international law and legal systems of particular states (obviously not all of them), encompassing various sectors, parts and branches of law.

However, the key question requiring answer is whether sustainable development-especially in the context of internationallaw-is in fact a legally binding norm? The answer to this question is not clear, and it is possible

14 D. V. Victor, Recovering Sustainable Development, Foreign Affairs, 2006, Vol. 95, p. 103. 
to indicate several leading approaches of this issue. Firstly, there is a theory of the normative character of sustainable development. For instance, according to K. Bosselmann, sustainable development is a legal principle. This view is justified "(...) with the normative character that the principle of sustainability has for the meaning of sustainable development. It follows that sustainability possesses the quality of a legal principle" ${ }^{16}$. Also P. Sands confirms the normative quality of sustainable development on grounds of the corpus of international customary law ${ }^{17}$. So - as the representatives of this approach claim - there should be no doubt, “(...) that sustainable development, as an objective, already constitutes a principle of customary law, even if this principle is a very general one, with a high degree of abstraction and which requires case by case substantiation" ${ }^{18}$.

Contrary to the first approach, the second one generally assumes that sustainable development can never become a part of customary international law. However, this does not mean that this concept is completely deprived of normative status. ${ }^{19}$ In this sense, of which the leading representative is V. Lowe, sustainable development is not itself a primary rule of (international) law, but "(...) it is a meta-principle, acting upon other legal rules and principles - a legal concept exercising a kind of interstitial normativity, pushing and pulling the boundaries of true primary norms when they threaten to overlap or conflict with each other"20. Thus, in spite of sustainable development not being a primary rule of international law, nor a principle of customary law, it may be perceived as an international policy objective ${ }^{21}$.

There is also a theory assuming that sustainable development is a conglomeration of procedural and substantive elements, of which some

16 K. Bosselmann, The Principle of Sustainability: Transforming Law and Governance, Aldershot 2008, p. 57.

17 P. Sands, Principles of International Environmental Law, Cambridge 2003, p. 254.

18 V. Barral, Sustainable Development in International Law: Nature and Operation of an Evolutive Legal Norm, European Journal of International Law 2012, Vol. 23, Issue 2, p. 388.

19 D. Tladi, Sustainable Development in International Law: An Analyses of Key EnviroEconomic Instruments, Pretoria 2007, p. 99.

20 V. Lowe, Sustainable Development and Unsustainable Arguments, in: International Law and Sustainable Development: Past Achievements and Future Challenges, eds. A. Boyle, D. Freestone, Oxford 1999, p. 30.

21 M.-C. Cordonier Segger, A. Khalfa, Sustainable Development Law. Principles, Practices, and Prospects, Oxford 2004, p 45-46. 
certainly are normative ${ }^{22}$. These elements include environmental protection, or more precisely - environmental law and regulations. However, there is, in general, a visible and clear tendency to recognize sustainable development rather as a policy objective, not a rule of law, but it cannot be excluded that this trend will ever change as a result of revision of the nature of this concept, which may be achieved by assigning it normative functions and values.

\subsection{Sustainable development in the Polish legal system}

The nature of sustainable development has been lively discussed by representatives of the Polish legal theory. It is due to the fact that this concept is a fundamental part of the Polish legal order, but at the same time, normative status and character of sustainable development - as in the case of international law - remains vague and unclear.

The importance of the concept of sustainable development in Polish law provides its regulation in the Constitution. According to article 5, "The Republic of Poland shall safeguard the independence and integrity of its territory and ensure the freedoms and rights of persons and citizens, the security of the citizens, safeguard the national heritage and shall ensure the protection of the natural environment, pursuant to the principle of sustainable development". Clearly, the cited article covers a number of different values (interests, goods) which must be respected and implemented by the state and - which is very important - sustainability applies equally to all of them. This is due to the catalogue of the interests set out in article 5 itself and established by the Constitution programme principle of sustainable development ${ }^{23}$.

The problem which should be resolved is the actual status of sustainability in terms of other principles expressed by the provisions of the Constitution. For it is not clear whether sustainable development should be perceived as an institutional principle or perhaps a principle of political nature. This matter is highlighted by Z. Bukowski, who claims that while considering the content of article 5 of the Constitution “(...) it seems that the principle

22 S. A. Atappatu, Emerging Principles of International Environmental Law, New York 2006, p. 182.

23 J. Zimmermann, Prawo administracyjne, Warszawa 2014, p. 132. 
of sustainable development refers to all of the general functions of the state enumerated there. This means that we are dealing with an institutional principle. Such assumption means that in article 5 we have a double regulation relating to the protection of the environment: 1 ) introduction of the principle of sustainable development as a constitutional principle concerning the fundamental tasks of the state, 2) the protection of the environment as one of the basic functions of the state" ${ }^{24}$. Therefore, public administration bodies are obliged to take this principle into account in their activity (while functioning for purposes of action and lines of action). This applies equally to bodies and authorities of executive, legislative and judicial powers. ${ }^{25}$

Polish Constitution does not define sustainable development in any way, but detailed definition of this concept can be found in substantive laws (mainly administrative law) which quite often take into account the issue of sustainable development in their provisions ${ }^{26}$. The exact and detailed definition of sustainability is contained in the Act of 27 April 2001 on Environmental Protection Law ${ }^{27}$, which in article 3 point 50 states that sustainable development "(...) is such socio-economic development, in which political, economic and social activities are integrated, while maintaining natural balance and permanence of basic natural processes in order to guarantee the ability to meet the basic needs of particular and individual communities or citizens of both the present generation and future generations".

At this point it should be indicated that some researchers claim that the attempts to defining this concept are-in advance-pointless, because it is not possible to comprehensively take into account wide variety of approaches to this issue. Thus, "(...) the concept of sustainable development in general should not be defined. (...) The principle of sustainable development should play in environmental law, the role played by the principles of social co-

\footnotetext{
24 Z. Bukowski, Konstytucyjne podstawy obowiązków państwa w zakresie ochrony środowiska, Prawo i Środowisko 2002, No 4, p 71.

25 J. Kielin-Maziarz, Koncepcja zrównoważonego rozwoju w prawie Unii Europejskiej, Lublin 2013, p. 73.

26 To sustainable development refers and invokes nearly 30 acts and a similar number of regulations.

27 Journal of Laws of 2001, No 62, item 627 with amendments, consolidated text.
} 
existence in civil law. It should be a general clause" ${ }^{28}$. However, B. Rakoczy does not question the normative nature of the concept of sustainable development. On the contrary, despite he sees sustainable development as a political principle, he also indicates the normative value (importance) of this concept $\mathrm{t}^{29}$.

A characteristic feature of the definition established by the provisions of Polish environmental law, is the extension of the concept of sustainable development to political actions and activities (next to economic and social activities), which seems to be quite consistent considering the influence of politics on the economy and society (micro and macro). This definition is therefore based on the need to integrate these areas in a way that leads to balance in nature, seen - according to article 3 point 32 of the Act on Environmental Protection Law - as a state (condition) in which in a specific area there is a balance in the mutual interaction of human, animate and inanimate natural resources. At the same time, besides integrating these political, economic and social activities in a way that preserves nature equilibrium, it is necessary to ensure the durability of basic natural processes, which requires actions or omissions directly leading to the preservation of this equilibrium ${ }^{30}$.

The abovementioned definition of sustainable development has, under Polish law, a universal character. This is due to the fact that according to the judicature of Polish administrative courts, public administration bodies should always verify and check whether the interference with environmental resources is permitted and justified in the context of sustainable development ${ }^{31}$. Moreover, the principle of sustainable development should be considered and implemented wherever we are dealing with regulations concerning the environment. It covers such substantive laws as for example water law, agricultural law, environmental law, forest law, etc. It is therefore a specific intersectoral definition. However, this does not mean, of course, that the Legislator may not introduce modified

B. Rakoczy, Definicje i zasady ogólne, in: J. Ciechanowicz-McLean, Z. Bukowski, B. Rakoczy, Prawo ochrony środowiska. Komentarz, Warszawa 2008, s. 48.

29 B. Rakoczy, Ograniczenie praw $i$ wolności jednostki ze względu na ochrone środowiska w Konstytucji Rzeczypospolitej Polskiej, Toruń 2006, s. 157.

30 M. Pchałek, in: Prawo ochrony środowiska. Komentarz, M. Górski, M. Pchałek, W. Radecki, J. Jerzmański, M. Bar, J. Jendrośka, S. Urban, Warszawa 2014, p. 91.

31 Judgment of the Voivodeship Administrative Court in Warsaw of 23 June 2009 r., IV SA/WA 1269/08, Legalis. 
concepts and definition of sustainable development (the most adequate and integrated with individual elements-sectors of the environment), but they should be coherent with the general framework of sustainable development set out in the Act on Environmental Protection Law.

While concluding this part of paper we should state that sustainability is - in the Polish legal system - rather a principle of law which has a normative meaning. At the same time, it is also an institutional (political) principle and a programme norm imposing realization of a specific aim, which is sustainable development as well ${ }^{32}$.

\section{Sustainable forest management (SFM)}

\subsection{Sustainable forest management - general remarks}

An example of a specific type of sustainable development includes the Polish forestry legislation and, more specifically, those regulations that relate to SFM. As it is indicated the forest science "(...) forests and forestry fit into the concept of sustainable development extremely accurately. It is in fact the object and the field of direct management and use of a particular resource, which when being used, codecides on the state of the entire wildlife and other natural resources, as wells as the whole environment. It is hard for a more evident link between the economic, natural and social values. Therefore, forest management cannot be excluded from the natural, economic and social environment. It cannot be surrounded by unsustainable management of other sectors and destructed natural environment. There must therefore be preconditions for sustainable development of forests and forestry, characterizing the political status of the state, general status of the economy, intersectoral links and an appropriate level of research, science and education" 33 .

32 Z. Bukowski, Koncepcja zrównoważonego rozwoju w dziatalności administracji publicznej, in: Administracja publiczna - cztowiek a ochrona środowiska. Zagadnienia spotecznoprawne, eds. M. Górski, J. Bucińska, M. Niedziółka, R. Stec, D. Strus, Warszawa 2011, s. 30.

33 K. Rykowski, O gospodarce leśnej w leśnych kompleksach promocyjnych, Sękocin Las 2005, p. 13 . 
Hence, there must be relevant provisions regulating these aspects enabling the synthesis and synergy of social, economic and environmental functions of forests through and by appropriate emerging and shaping of the structure and management of forests (SFM). This is possible due to specific directives of behaviour (proceedings) addressed to public administration bodies and forest owners (especially by introducing a system of orders) which are introduced by the provisions of the Act on Forests.

The interactions resulting from synergies and connections of these three fundamental (from the point of view of sustainable development) social, economic and environmental components are therefore particularly evident in forestry, which can be a model approach to the sustainable development in micro-scale and that is why this factor determines the value and relevance of research on SFM (legal institutions which are supposed to ensure its implementation). Moreover, this view is reinforced by the fact that the whole concept of sustainable development stems essentially from forestry. As K. Bosselmann indicates, the idea of sustainability has been introduced as a direct effect of almost complete deforestation caused by agricultural development (during the first half of the 14th century). People suffered starvation because of the lack of timber and food, and these factors caused as a result - outbreak of the most devastating plague in both European and human history, which was the Black Death. For that reason, “(...) in response to the crisis, local principalities and townships took measures of large-scale reforestation and enacted laws based on sustainability. The idea was to not clear more wood than would grow again and to plant new trees so that future generations would benefit" 34 . Also the origins of the term "sustainability" are linked to forestry. This term has been created by a forest scientist who tried to find out - in his research and analysis - how "conservation and growing of timber can be managed in order to provide continued, durable and sustained use" 35 .

As we already know forestry and forest science played a crucial role in the emergence of the concept of sustainable development and that sustainable development is a key concept in today's forestry and forestry law, which is reflected in the form of the desired (by the Polish Legislator) model of forest management - SFM. So, in more general terms, this means that the history of sustainable development is essentially a history of SFM. The concept

K. Bosselmann, The Principle, p. 14.

35 Ibidem, p. 18, footnote 27. 
of sustainable development emerged from the conviction of the finiteness of natural resources and the need to take into consideration - in socioeconomic development - the necessity of protection of the environment and its resources. Development of modern and current concepts of SFM was initiated by deforestation as a result of commercial logging ${ }^{36}$.

No wonder that the basic principles of SFM were developed during the Conference in Rio de Janeiro devoted to the protection of the environment in the context of socio-economic development. One of the key documents of the Conference - besides Rio Declaration on Environment and Development and Agenda 21 - are Forest Principles - the very first international document on SFM. This does not mean that previous documents devoted to sustainable development (such as for instance the Brundtlund Report) did not relate to forestry. However, Forest Principles concern this issue in a direct and unambiguous way ${ }^{37}$.

Forest Principles, first global consensus on forests adopted in 1992, are - as the full name of this document states - Non-Legally Binding Authoritative Statement of Principles for a Global Consensus on the Management, Conservation and Sustainable Development of All Types of Forests. This means that they are soft-law instruments based on recommendations providing desirable worldwide practises for SFM and development. However, the role of Forest Principles - despite their nonlegally binding nature - cannot be overestimated. This document initiated a number of international activities, such as for example the adoption of Non-Legally Binding Instrument on All Types of Forests in 2007, The Collaborative Partnership on Forests or the Montreal Process, which main objective is to ensure the implementation of SFM. At the same time, the adoption of a legally binding agreements is not excluded. For example, in the EU Ministerial Conferences on the Protection of Forests in Europe have been held annually since 1990. During the Conference in Oslo in 2011 the decision was made to undertake the preparations on a Legally Binding Agreement on Forests in Europe. Also during these Conferences the definition of sustainable forest management was developed, according

36 K. Forstbauer, J. Parker, The Role of Ecolabeling in Sustainable Forest Management, Journal of Environmental Law and Litigation 1996, No 11, pp. 170-171.

37 See: E. B. Kasimbazi, An International Legal Framework for Forest Management and Sustainable Development, Annual Survey of International \& Comparative Law 1995, Vol. 2, Issue 1, p. 70-86. 
to which, “(...) the stewardship and use of forests and forest lands in a way, and at a rate, that maintains their biodiversity, productivity, regeneration capacity, vitality and their potential to fulfill, now and in the future, relevant ecological, economic and social functions, at local, national, and global levels, and that does not cause damage to other ecosystems"38.

\subsection{Sustainable forest management in the Polish legal system}

This definition fully fits in with the definition of SFM stipulated by the Act on Forests, which is the basic and fundamental legislative act regulating the functioning of forest ecosystems in Poland.

According to article 1, the Act on Forests "sets out principles for the retention, protection and augmentation of forest resources, as well as for the management of forests and other elements of the environment in reference to the national economy". The wording of this article clearly shows the hierarchy of actions which should be taken in relation to forests, and also indicates that the forest is not an autonomous system, but it determines the functioning of the whole environment and the forest economy is strongly linked to the national economy. At the same time, forest resources are defined as good, because of which relations under administrative law, arise, change and cease ${ }^{39}$.

The Act on Forests defines forest management as “(...) activity in a forest in respect of the utilisation, protection and management thereof; the maintenance and augmentation of forest resources and plantations; game management; the acquisition - other than by purchase - of wood, resin, Christmas trees, stumpwood, bark, needles, game animals and products of the forest floor vegetation; as well as the sale of these products and the securing of the non-productive functions of forest" (article 6, item 1, point 1).

Generally, this means that forest management is based on the use of both forest and maintaining its durability, and is focused on the implementation

38 E. Paavilainen, The Concept of Sustainable Management in Boreal and Temperate Forests. IUFRO News 1994, Vol. 23, Issue 3, p. 8-9

39 L. Klat-Wertelecka, Administracyjnoprawne instrumenty ochrony lasów, in: Ochrona i użytkowanie zasobów leśnych, eds. M. Woźniak, M. Kościelniak-Marszał, Wrocław 2015, p. $102-103$. 
of not only productive (economic) functions but also non-productive (noneconomic) functions of forest ecosystems. Economic functions of the forest depend on logging, by-products (e.g. fungi or resin) and game. On the other hand, non-economic functions are divided into ecological (protective) and social functions and comprise of: influence on the climate, the environment and human life and providing a natural place for recreation (recreational functions $)^{40}$. The existing model of forest management moves away from monofunctional forestry in favor of multifunctional forestry. Multifunctional role of forests is the object and purpose of SFM. Therefore, forestry is one of the instruments of sustainable development determining the existence of the forest ecosystems ${ }^{41}$.

This kind of forest management is carried out on the basis of principles which ensure the multifunctional nature and characteristics of forests. These principles were expressed in the article 8 of the Act on Forests, on grounds of which forest management is pursued in accordance with the principles of: 1) the universal protection of forests; 2) the persistent maintenance of forests; 3) continuity and the sustainable use of all forest functions; and 4) ongoing augmentation of forest resources. The third of these enumerated principles relates to SFM and has been specified by the Legislator in several provisions of the Act on Forests. At this point, it is necessary to examine and discuss these provisions in order to indicate the role which they play in terms of implementation of the principle of SFM (which indirectly means also the principle of sustainable development in genere).

In the first place article 7 of the Act on Forests should be noted. It states, that SFM is engaged in pursuant to a Forest Management Plan or simplified Forest Management Plan. Initially the concept of SFM was not included in the provisions of the Act on Forests and was added to it five years after its entry into force (i.e. in 1997). This manifested, on the one hand, putting an end to the model of monofunctional forest management and, on the other hand, the harmonization of the objectives of forest management with the concept of sustainable development.

According to legal definitions stipulated by the Act on Forests, SFM means "(...) activity seeking to shape the structure of forests and make use

40 R. Jaszczak, Funkcje lasów, in: Propedeutyka leśnictwa, W. Kusiak, R. Jaszczak, Poznań 2009, pp. 62-63.

${ }_{41}$ P. Paschalis-Jakubowicz, Uwarunkowania strategii rozwoju Lasów Państwowych, Warszawa 2012, p. 27. 
of them in a manner and at a rate ensuring the permanent protection of their biological diversity, a high level of productivity and regeneration potential, vitality and a capacity to serve - now and in the future - all the important protective, economic and social functions at local, national and global levels, without harm being done to other ecosystems" (article 6, item 1, point 1a). It is clear, as I mentioned earlier, that the definition of SFM adopted by the Polish legislature almost entirely coincides with the definition of SFM established and developed by Ministerial Conferences on the Protection of Forests in Europe. The central issue of forest management defined in such a way is its multifunctional character based on long-term assumptions, which at the same time is, at least, harmless (neutral) to other ecological systems.

The basic tool for enabling SFM is the already mentioned Forest Management Plans. Pursuant to legal definition stipulated by the Act on Forests, they are "(...) primary forest management document drawn up for a given area and containing a description and assessment of the condition the given forest is in, as well as the objectives, tasks and methods of forest management" (article 6, item 1, point 6). Forest sciences indicate, that Forest Management Plan „(...) is the result of forest inventory, analysis of forest management operations conducted in the past and the result of the application of a specific regulatory regime. It provides Forest Services information on where and how to conduct economic proceedings (..." ${ }^{\prime 42}$. These Plans are divided into two types depending on the ownership of forests, to which they are supposed to be drawn up.

The first category includes Forest Management Plans developed for the State Forests (owned by the Treasury). These types of Plans, basically, shall be drawn up for 10 years (in some cases it may be shorter period if, for example forest was affected by a natural disaster) and it must take into account natural and economic conditions of forest management, as well as the objectives and principles of forest management and ways of their implementation, specified for each stand and managed object, with regard also being had to protective forests ${ }^{43}$. As B. Rakoczy accurately points out,

42 R. Miś, Urządzanie lasów wielofunkcyjnych, Poznań 2007, p. 270.

43 Protective forests are specific types of forests implementing non-productive functions (particularly environmental and social). Their primary and main purpose of existence is to provide the protection of certain elements (animate and/or inanimate) of the environment or being protected in situations specified in the Act on Forests. J. Chmielewski, Lasy 
(...) a reference to the natural elements and at the same time economic elements in the context of forest management is in fact a reference to the principle of sustainable development" 44 . This opinion should be fully shared, especially if we take into account the fact, that these planning documents are key tools which make the SFM implementation possible. The public administration body which is relevant in approving Forest Management Plans in respect of forests constituting Treasury property is the Minister relevant in matters of the environment (article 22, item 1 and 4). Forest Management Plans - according to article 20 of the Act on Forests - should be taken into account in local planning documents (Local Physical Development Plans stipulating intended use of land, public-purpose investment locations, identifying ways to zoning and land development conditions), and also in the registration of land and buildings (the register of land, buildings and premises containing data of entities who are wielding them). This particularly means, that any changes made in the Local Physical Development Plans and in the registration of land and buildings cannot conflict with the provisions of the Forest Management Plans.

The second type (category) of Forest Management Plans are Simplified Forest Management Plans, which - in principle - are drawn up for forests not constituting Treasury property (and also for forests forming part of the Treasury Agricultural Property Resource). Simplified Plans are drawn up for forests owned by individuals, community organizations, local governments and so on, but such forests cannot be fragmented and their areas must be at least 10 ha. Simplified Plans are approved - after receiving the opinion of the relevant District Forest Manager - by relevant public administration body which is starosta (article 22, item 2). According to article 22, item 5 of the Act on Forests starosta is also responsible for supervising the effecting of approved Simplified Forest Management Plans in respect of forests that do not constitute Treasury property.

The common element for Forest Management Plans and Simplified Forest Management Plans is that they are both drawn up by specialist units or other entities engaging in management (article 19, item 5 of the Act on Forests). Furthermore in both cases, the Polish Legislator, unfortunately,

ochronne. Przyczynek do rozważań nad administracyjno-prawna problematykq lasów szczególnie chronionych, Przegląd Prawa Ochrony Środowiska 2014, No 4, p. 94.

44 B. Rakoczy, Ustawa o lasach. Komentarz, LexOmega. 
did not indicate the criteria and surveillance measures conducted on the plans, nor did they specify the way of executing these plans, i.e. the reporting and evaluation of the implementation ${ }^{45}$. As a consequence, there is no feedback provided "(...) between public administration body which is responsible for the approval and execution of a Plan and units which develop and implement this Plan" ${ }^{46}$. These deficits should be definitely criticised. It is because they may significantly foreclose and limit the implementation of SFM implemented by means of (Simplified) Forest Management Plans. It should also be emphasized that - as quoted representatives of forest science claim - "(...) forest management plan as the primary document, according to which forest management is conducted in the State Forests shall also include economic conditions and consequences of its implementation. (...). When planning forest management activities, they should be (...) linked to economic conditions" 47 .

As it is already known, both Forest Management Plans and Simplified Forest Management Plans are basic planning documents in forestry. SFM is implemented and conducted on the basis of these Plans and it should take into account - as indicated by the Legislator in article 7, item 1 of the Act on Forests - precisely defined objectives which may be divided into three basic groups.

The first group of objectives concerns the forests themselves, and more specifically it concerns (1) the conservation of forests and their beneficial effect on the particular components of the environment and preservation of natural balance between them, and (2) the protection of forests, with particular emphasis on those forest ecosystems that are natural parts of a national nature or are especially valuable because of the preservation of biological diversity, forest genetic resources, features of the landscapes and the needs of science.

The second group of objectives concerns the protection of the components of terrestrial ecosystems which appear in forests or create forest ecosystems. On the one hand, it comes to the protection of soils and areas vulnerable

45 K. Karpus, Prawo leśne - plan urządzenia lasu, in: Wybrane problemy prawa leśnego, ed. B. Rakoczy, Warszawa 2011, pp. 77-78.

${ }^{46}$ J. Głaz, J. Czerepko, M. Jabłoński, G. Zajączkowski, Kierunki doskonalenia zasad urzadzania lasu w celu realizacji trwale zrównoważonej gospodarki leśnej, Sylwan 2008, No 1, p. 43.

47 Ibidem, p. 41. 
to pollution, damage, or areas that have special social significance. On the other hand, these objectives should take into account the protection of waters (surface and underground waters) and drainage-basin retention.

The third and at the same time the last group of objectives, which may be extracted on grounds of the Act on Forests must consider - while conducting SFM based on the (Simplified) Forest Management Plans timber production matters, raw materials and by-products of forests (e.g. products of the forest floor vegetation such as fungi, berries, herbs and so on). At the same time, as Legislator claims, production should take place "on the basis of rational management". Underlining such a character of the economic functions of forests is, in my opinion, an additional argument in favor of strengthening the implementation of SFM. It is clear that the implementation of this type of forest management requires a very rational (thoughtful, reasonable) management of forests.

Moreover, Polish lawmaker has defined exemplary responsibilities (obligations), by means of which SFM is carried out. They are therefore tools of SFM implementation. These obligations were introduced by article 13a of the Act on Forests, which in item 2 defines them as tasks. These obligations are not executive authorities but they rather remain in the inner sphere of the States Forest administration and cause no legal effects ${ }^{48}$. Polish lawmaker identified a catalog of three groups of obligations.

First group is addressed only to the State Forests and it encompasses not only initiating, coordinating and making periodic assessments of the condition of forests and forest resources, but also forecasting potential changes in forest ecosystems. Periodic assessments are concluded in annual reports and allow to continuously monitor the condition of forests and forest resources, and to predict potential changes in this field. The second group of obligations (tasks) applies equally to all forests, regardless of their form of ownership. It embraces engaging in the periodic, large-scale inventorying of the condition of forests and updating records as regards forest resources. According to the current methodical guidelines on inventories, they are supposed to "(...) constitute the primary source of data on forests and changes occurring in them, as well as direct and indirect human activities in forest areas, both in the country and regions" ${ }^{\prime 9}$. As the Guidelines underline,

48 See: J. Zimmermann, Aksjomaty prawa administracyjnego, Warszawa 2013, p. 172-184.

49 Instrukcja wykonywania wielkoobszarowej inwentaryzacji stanu lasu, zatwierdzona przez Ministra Środowiska w dniu 15 lutego 2005 r., Warszawa 2004, p. 4. 
such inventories are a prerequisite for Polish participation in international processes concerning forests and forestry, including also the processes of sustainable development $t^{50}$. Third group of duties also applies to all types of forests (private and public) and it obliges relevant authorities to run a data bank on forest resources and the condition of forests. The essence of this requirement is the collection of data on forests and their condition. This data is then used, analyzed and processed. This (perfunctory) analysis clearly shows that the fundamental objective of the abovementioned obligations and requirements is the implementation of SFM by continuous monitoring the condition of forests and forest resources and feedback concerning this issue. As a result, it enables the introduction or modification of activities that fully contribute to the implementation of the desired by Polish legislature model of forest management, namely SFM.

However, the actual implementation of SFM requires promotional and educational activities and undertakings which will constantly contribute to increasing the awareness of the citizens in this matter. That is why lawmaker introduced the institution of Promotional Forest Complexes, which - in accordance with the provisions of the Act on Forests - are "(...) functional areas of ecological, educational and social importance, whose activity shall be set out in a single management and protection programme drawn up by the appropriate Director at a Regional Directorate of the State Forests" (article 13b, item 3). They comprise of forests managed by the State Forests, but the possibility of extending them to cover others forms of forest ownership is not excluded, provided that owners request it. Each Promotional Forest Complex has its own Scientific and Social Council, constituted by the regulation of the Director-General of the State Forests, which tasks include the initiation and assessment of actions taken within the Promotional Forest Complex.

The main, but not the only task of Promotional Forest Complexes is according to article 13b, item 1 of the Act on Forests - promotion of SFM. Furthermore, in compliance with the abovementioned article, Promotional Forest Complexes are supposed to protect natural resources, but at the same, they are not competitive forms of nature conservation for e.g. national parks, nature reserves or landscape parks. These forms, instead of competing, rather co-exist and complement one another ${ }^{51}$. Besides the promotion of SFM,

50 Ibidem, p. 4.

51 W. Radecki, Ustawa o lasach. Komentarz, Warszawa 2012, p. 122. 
as a goal of introducing the institution of Promotional Forest Complexes, is also indicated "(...) the consideration of natural and anthropogenic changeability in macro-scale of the forests in Poland and creation of a real basis for further work on the proper regionalization of forest management carried out in-depth environmental grounds" ${ }^{2}$. Considering these objectives it should be stated, that the establishment of Promotional Forest Complexes is a genuine and original Polish contribution to global SFM based on economic fundamentals, natural and social expectations towards forests ${ }^{53}$.

However, the fundamental legal problem which should be necessarily solved is the issue of measuring implementation of SFM and - bearing in mind that it is one of the general principles of forest management introducing legislation by which it would be possible, of course if only necessary, to revise and adjust forest management in order to orient it on sustainable.

The most common indicator of the implementation of SFM is the timber increment/harvesting ratio. Such method of measurement is rather imperfect, due to the fact that this index "(...) stems largely from the age structure of the forest, that is characterised by considerable share of stands with a large increment and relatively low use. With the passage of time, the situation may change and indicators increase, what should not be equated with the operational running of forest management. The value of this index is also affected by the extreme weather conditions, primarily hurricane winds, and biotic damages (insects, fungi), that can cause largeforest damage, resulting in increased acquisition of wood biomass" ${ }^{24}$.

Hence, there is an evident need for standardization of methods and indicators of SFM measurement, and above all, the need to develop and, next, to conceptualize in the legal framework their implementation. As pointed out in the literature of forest science, forest management steadystate can be achieved only by means of legal solutions while taking into account natural and social functions performed by forest ecosystems ${ }^{55}$. Legal

\footnotetext{
52 Z. Rozwałka, Funkcje i zadania leśnych kompleksów promocyjnych, in: Użytkowanie produktów leśnictwa wielofunkcyjnego w warunkach transformacji gospodarczej, ed. Z. Laurow, Warszawa 1997, p. 87.

53 Ibidem, p. 87.

54 Raport o stanie lasów w Polsce 2013, Warszawa 2014, p. 44.

55 J. Głaz, Zarys koncepcji zrównoważonego rozwoju gospodarstwa leśnego w regionie uprzemystowionym, Warszawa 2004, p. 7.
} 
instruments providing standarised ways and indicators of measurement of SFM could by introduced by adding to the Act on Forests statutory authorization for Minister relevant in matters of the environment to lay down, by virtue of a regulation, detailed provisions concerning this matter. It is about adopting provisions, in particular, regulating rules and methods of measurements, as well as measurement criteria, which could, for example, encompass: maintaining and enhancing forest resources and their contribution to the overall carbon balance; maintaining the health of forest ecosystems, maintaining and strengthening the productive functions of forests; preserving, protecting and strengthening the biological diversity of forest ecosystems; maintaining and strengthening the protective functions of forests; maintaining other socio-economic function $s^{56}$.

When it comes to regulations involving the possibility of state interference, when the results of measurements of SFM would confirm the dysfunctions within specific areas of forest (forest precincts), there the adoption of the relevant provisions in the Act on Forests should be considered. Such provisions could authorise relevant public administration bodies to take official actions aimed at correcting (minimizing) identified dysfunctions. For instance, these actions, in case of private forests, could be administrative decisions of starost. Certainly, such provisions and actions would contribute to better monitoring and implementation of SFM.

\section{Summary}

In general, sustainable development is, what I tried to express in the first part of this article, a very ambiguous concept. At the same time it occurs and it is a subject of study of various scientific disciplines, which complicates already existing confusion even more.

One of the essential elements (pieces, parts) of sustainable development is SFM ${ }^{57}$, and it is forestry from where the concept of sustainability

56 J. Głaz, Kryteria i wskaźniki trwatej i zrównoważonej gospodarki leśnej w planowaniu urzadzeniowym, Warszawa 2008, pp. 11-15.

57 M. Walas, Korzystanie z lasów a trwale zrównoważona gospodarka leśna, in: Prawne aspekty gospodarowania zasobami środowiska: korzystanie z zasobów środowiska, eds. B. Rakoczy, M. Szalewska, K. Karpus, Toruń 2014, p. 371. 
and sustainable development emerged. At the same time, "the concept of sustainable development is transferred to the ground of the forest law through concept of sustainable forest management" ${ }^{\text {" }}$.

Basically SFM is based on such management and use of forests in which social, economic and environmental (ecological) needs of present and future generations are considered and implemented. In Poland it occurs in a departure from the current monofunctional model of forest management and, at the same time, adoption of multifunctional forest management ${ }^{59}$. Polish idea of SFM is very close to the international definitions of this conception. In my opinion, the existing definition of SFM refers to original assumptions of sustainability. Therefore, based on the pictorial conceptualization of the concept of sustainable development from the Brundtland Report period ${ }^{60}$ we are able to illustrate SFM in this way:

Economic Functions of Forests

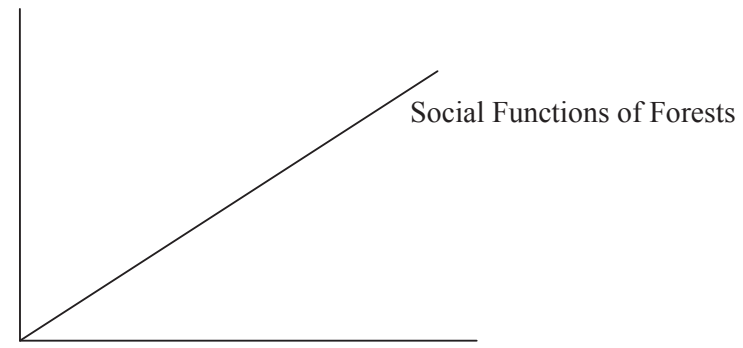

Ecological Functions of Forests

This analysis clearly shows that the Polish Legislator pays special attention to SFM. It is realized - as part of sustainable development in genere - through and by the planning acts, forecasting, coordinating and finally promotion undertakings. The fundamental tools are planning acts, which remain the key instruments of forest management.

Implementation of SFM is an indisputable fact. However, this does not mean that we should neglect new solutions in this field ${ }^{61}$. It also concerns legal solutions. It seems that the matter, which requires legislative

$58 \quad$ Z. Bukowski, Koncepcja zrównoważonego..., p. 101.

59 J. Głaz, Zasady funkcjonowania zrównoważonego gospodarstwa leśnego na przyktadzie regionu uprzemystowionego, Sękocin Stary 2007, p. 108.

60 B. S. Malaynag III, Rethinking, p. 119.

61 P.Paschalis-Jakubowicz, Teoretyczne podstawy i realizacja idei zrównoważonego rozwoju w leśnictwie, Problemy Ekorozwoju 2001, Vol. 6 No 2, s. 105. 
intervention, is the issue of the criteria and measurement of effective implementation of SFM. It is also about introducing regulations which could form legal grounds for imperative actions of relevant public administration bodies allowing them to interfere wherever measurements would indicate disfunctions of SFM.

\section{Bibliography}

Atappatu S. A., Emerging Principles of International Environmental Law, New York 2006.

Barral V., Sustainable Development in International Law: Nature and Operation of an Evolutive Legal Norm, European Journal of International Law 2012, Vol. 23, Issue 2.

Blewitt J., Understanding Sustainable Development, London 2008.

Bosselmann K., The Principle of Sustainability: Transforming Law and Governance, Aldershot 2008.

Buchs A., Blanchard O., Exploring the Concept of Sustainable Development Through Role-Playing, The Journal of Economic Education 2011, Vol. 42 No 4.

Bukowski Z., Konstytucyjne podstawy obowiązków państwa w zakresie ochrony srodowiska, Prawo i Środowisko 2002, No 4.

Bukowski Z., Koncepcja zrównoważonego rozwoju a gospodarka leśna, in: Ochrona i użytkowanie zasobów leśnych, eds. M. Woźniak, M. Kościelniak-Marszał, Wrocław 2015

Bukowski Z., Koncepcja zrównoważonego rozwoju w dziatalności administracji publicznej, in: Administracja publiczna - cztowiek a ochrona środowiska. Zagadnienia spoteczno-prawne, eds. M. Górski, J. Bucińska, M. Niedziółka, R. Stec, D. Strus, Warszawa 2011.

Bukowski Z., Sustainable development in legal system, Torun 2009.

Chmielewski J., Lasy ochronne. Przyczynek do rozważań nad administracyjno-prawna problematyka lasów szczególnie chronionych, Przegląd Prawa Ochrony Środowiska 2014, No 4.

Cordonier Segger M. C., Khalfa A., Sustainable Development Law. Principles, Practices, and Prospects, Oxford 2004.

Fergus A. H. T., Rowney J. I. A., Sustainable Development: Lost Meaning and Opportunity?, Journal of Business Ethics 2005, Vol. 60.

Forstbauer K., Parker J., The Role of Ecolabeling in Sustainable Forest Management, Journal of Environmental Law and Litigation 1996, No 11.

Fredericks S., Measuring and Evaluating Sustainability, London and New York 2013. 
Gherasim M. E., Tanase G., The Fundamentals of Sustainable Development, Contemporary Readings in Law and Social Justice 2012, Vol. 4, No 1.

Głaz J., Kryteria $i$ wskaźniki trwatej $i$ zrównoważonej gospodarki leśnej w planowaniu urządzeniowym, Warszawa 2008.

Głaz J., Zarys koncepcji zrównoważonego rozwoju gospodarstwa leśnego w regionie uprzemystowionym, Warszawa 2004.

Głaz J., Zasady funkcjonowania zrównoważonego gospodarstwa leśnego na przykładzie regionu uprzemystowionego, Sękocin Stary 2007.

Głaz J., Czerepko J., Jabłoński M., Zajączkowski G., Kierunki doskonalenia zasad urzadzania lasu w celu realizacji trwale zrównoważonej gospodarki leśnej, Sylwan 2008, No 1.

Instrukcja wykonywania wielkoobszarowej inwentaryzacji stanu lasu, zatwierdzona przez Ministra Środowiska w dniu 15 lutego 2005 r., Warszawa 2004.

Jaszczak R., Funkcje lasórw, in: Propedeutyka leśnictwa, W. Kusiak, R. Jaszczak, Poznań 2009.

Karpus K., Prawo leśne - plan urządzenia lasu, in: Wybrane problemy prawa leśnego, ed. B. Rakoczy, Warszawa 2011.

Kasimbazi E. B., An International Legal Framework for Forest Management and Sustainable Development, Annual Survey of International \& Comparative Law 1995, Vol. 2, Issue 1.

Kielin-Maziarz J., Koncepcja zrównoważonego rozwoju w prawie Unii Europejskiej, Lublin 2013.

Klat-Wertelecka L., Administracyjnoprawne instrumenty ochrony lasórw, in: Ochrona i użytkowanie zasobów leśnych, eds. M. Woźniak, M. Kościelniak-Marszał, Wrocław 2015.

Lowe V., Sustainable Development and Unsustainable Arguments, in: International Law and Sustainable Development: Past Achievements and Future Challenges, eds. A. Boyle, D. Freestone, Oxford 1999.

Malaynag III B. S., Rethinking Sustainable Development, Philippine Law Journal 2006, Vol. 81.

Miller Th., Reconstructing Sustainability Science. Knowledge and Action for a Sustainable Future, Routledge 2014.

Miś R., Urządzanie lasów wielofunkcyjnych, Poznań 2007.

Osofsky H. M., Defining Sustainable Development After Earth Summit 2002, Loyola of Los Angeles International and Comparative Law Review 2003, Vol. 26.

Paavilainen E., The Concept of Sustainable Management in Boreal and Temperate Forests. IUFRO News 1994, Vol. 23, Issue 3.

Paschalis-Jakubowicz P., Uwarunkowania strategii rozwoju Lasów Państwowych, Warszawa 2012.

Paschalis-Jakubowicz P., Teoretyczne podstawy $i$ realizacja idei zrównoważonego rozwoju w leśnictwie, Problemy Ekorozwoju 2001, Vol. 6, No 2. 


\section{Jan Chmielewski}

Pezzoli K., Sustainable Development: A Transdisciplinary Overview of the Literature, Journal of Environmental Planning and Management 1997, Vol. 40.

Environmental law. Commentary,M. Górski, M. Pchałek, W. Radecki,J.Jerzmański, M. Bar, J. Jendrośka, S. Urban, Warszawa 2014.

Radecki W., Ustawa o lasach. Komentarz, Warszawa 2012.

Rakoczy B., Definicje i zasady ogólne, in: J. Ciechanowicz-McLean, Z. Bukowski, B. Rakoczy, Prawo ochrony środowiska. Komentarz, Warszawa 2008.

Rakoczy B., Ograniczenie praw i wolności jednostki ze względu na ochrone środowiska w Konstytucji Rzeczypospolitej Polskiej, Torun 2006.

Rakoczy B., Ustawa o lasach. Komentarz, LexOmega.

Raport o stanie lasów w Polsce 2013, Warszawa 2014.

Robert K. W., Parris Th. M., Leiserowitz A. A., What is Sustainable Development?

Goals, Indicators, Values, and Practice, Environment: Science and Policy for Sustainable Development 2005, Vol. 47, Issue 3.

Rozwałka Z., Funkcje i zadania leśnych kompleksów promocyjnych, in: Użytkowanie produktów lesnictwa wielofunkcyjnego w warunkach transformacji gospodarczej, ed. Z. Laurow, Warszawa 1997.

Rykowski K., O gospodarce leśnej w leśnych kompleksach promocyjnych, Sękocin Las 2005.

Sands P., Principles of International Environmental Law, Cambridge 2003.

Sustainability. Key Issues, eds. H. Kopnina, E. Shoreman-Ouimet, New York 2015.

Theories of Sustainable Development, eds. J. Enders, M. Remig, London 2014.

Tladi D., Sustainable Development in International Law: An Analyses of Key Enviro-Economic Instruments, Pretoria 2007.

Transdisciplinary Sustainability Studies. A Heuristic Approach, eds. K. Huutoniemi, P. Tapio, London 2014.

Values in Sustainable Development, ed. J. Appleton, Routledge 2015.

Victor D. V., Recovering Sustainable Development, Foreign Affairs, 2006, Vol. 95.

Walas M., Korzystanie z lasów a trwale zrównoważona gospodarka leśna, in: Prawne aspekty gospodarowania zasobami środowiska: korzystanie z zasobów środowiska, eds. B. Rakoczy, M. Szalewska, K. Karpus, Torun 2014.

Williams C. C., Millington A. C., The Diverse and Contested Meanings of Sustainable Development, The Geographical Journal 2004, Vol. 170, No 2.

Zimmermann J., Aksjomaty prawa administracyjnego, Warszawa 2013.

Zimmermann J., Prawo administracyjne, Warszawa 2014.

\section{Email}

jchmielewski@kozminski.edu.pl 